\title{
Challenges of periodontal plastic surgery in a depressed economy: a report of two cases
}

This article was published in the following Dove Press journal:

Research and Reports in Tropical Medicine

3I August 2010

Number of times this article has been viewed

\section{Solomon O Nwhator \\ Department of Preventive and Community Dentistry, Obafemi Awolowo University, Ile-Ife, Nigeria}

Correspondence: Solomon O Nwhator 22 Potters Lane, M9 4LF, Manchester, UK Email nwhator32@yahoo.com

\begin{abstract}
Advancements in restorative dentistry have resulted in people keeping their teeth for longer, and an increase in gingival recession as the gums recede due to age, periodontal disease, thin gingiva, or other factors. The demand for periodontal plastic surgery appears to be increasing. Several methods have been used in the treatment of denuded roots. Of these, the free gingival autograft, the coronally displaced flap, guided tissue regeneration, and, lately, the connective tissue graft appear to be the main methods employed. There are as yet no reports of periodontal plastic surgery performed in Nigeria. We report two cases of Miller's Class 2 gingival recession treated by free gingival autografts in the specialist periodontal clinic of a South-Western teaching hospital in Nigeria. The challenges of awareness, a dearth of expertise, cost of materials, consequent cost of treatment, and how these affect the accessing of treatment are highlighted. The methods used in getting over these hurdles to provide treatment are also discussed.
\end{abstract}

Keywords: gingival recession, free gingival autograft, Nigeria

\section{Introduction}

There has been a metamorphosis of sorts since Friedman's proposition of the term "mucogingival surgery" over half a century ago. This type of surgery was originally supposed to involve three key elements, namely preservation of the attached gingiva, frenectomy/frenotomy, and vestibuloplasty. ${ }^{1}$ The last two decades, however, have seen the development of these initial criteria into a definite field of periodontal plastic surgery with the aim "to regenerate form, function and aesthetics of teeth, implants, and hard and soft tissues". 2

The current state of the art practice in periodontal plastic surgery involves surgical microscopes ${ }^{2}$ and advanced microsurgical techniques used in the regeneration of form and aesthetics, as well as in the restoration of function. It now involves not just treating the sequelae of chronic periodontitis but also those of peri-implantitis.

The art of periodontal plastic surgery is still in its elementary stages in Nigeria, and the two cases reported here represent early attempts at periodontal plastic surgery in a specialist periodontal clinic at a teaching hospital in South-Western Nigeria.

\section{Case report I: Free gingival autograft}

A Nigerian woman in her mid-twenties was referred to the periodontal clinic and found to have localized gingival recession affecting teeth 31, 32, and 41 (Figure 1a). The recession was conservatively classified as Miller's Class 2 on teeth 31 and 32, and Class 1 on tooth 41 . All affected teeth were periodontally stable, with all pocket depths 
less than $3.5 \mathrm{~mm}$ and very minimal horizontal alveolar bone loss. The patient had moderately fair oral hygiene and there was no history of previous orthodontic treatment involving the affected teeth. The labial vestibule was also slightly shallow with some evidence of frenal pull, as clearly displayed in the postoperative picture (Figure 1b). The frenal pull, acting in consonance with the presence of calculus, appeared to be the cause of the recession seen in the affected teeth. Traumatic brushing was not thought to play a major role, as evidenced by the fact that the canines were spared bilaterally. The patient was also medically fit, with no history of medical conditions that could adversely affect periodontal status.

After initial oral prophylaxis, the recessions were treated using a free gingival autograft harvested from the palate opposite the upper left molar teeth (Figure 1b). The graft was sutured in place over the prepared recipient site using 6-0 Vicryl sutures under minimal tension (Figure 1c). Initial hemostasis was achieved using digital pressure at the surgical site, and the surgical wound was covered with a protective periodontal dressing. The donor site was allowed to heal by secondary intention through granulation.

At three-week review, the surgical site showed good healing of donor and recipient sites, increased width of healthy keratinized gingiva, but only minimal root coverage was achieved (Figure 1d).

\section{Case report 2: Free gingival autograft}

An adult male Nigerian patient referred to the specialist periodontal clinic presented with localized gingival recession on a slightly buccally-displaced tooth 43 (Figure 2a).
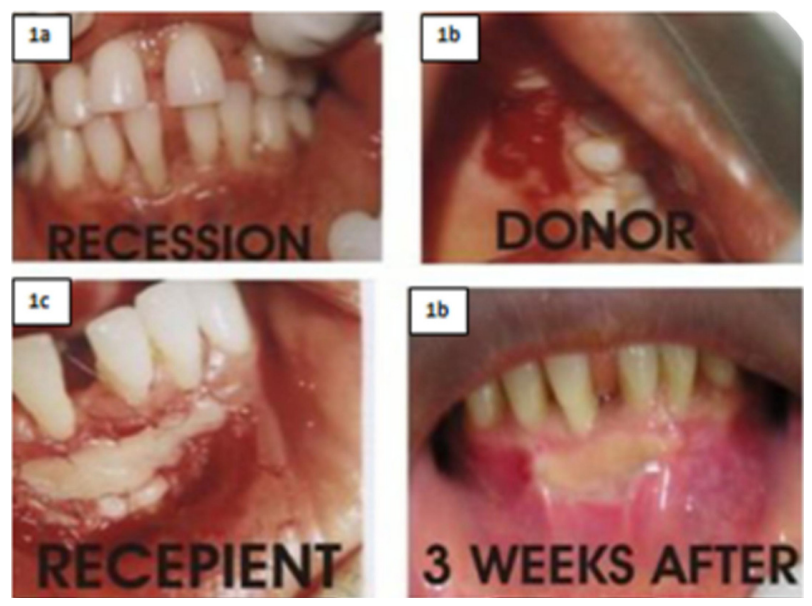

Figure I Free gingival autograft for treatment of recession on tooth 3I, 32, and 4I.
The lesion was classified as a toothbrush-induced Miller's Class 2 gingival recession with minimal bone loss.

The patient had good oral hygiene, with very minimal deposit both on the affected tooth and the rest of the mouth. He was periodontally stable with no pockets greater than $3.5 \mathrm{~mm}$. Two factors seen on examination seemed to be responsible for the gingival recession, namely gingival frenal pull and wrong brushing technique, with the second probably playing a more prominent role. The vulnerability of the affected tooth based on its position in the mouth (being a canine), as well as good oral hygiene, appeared to support this view.

After initial oral debridement, the defect was covered with a free gingival autograft harvested from the palate opposite the upper left molar teeth (Figure $2 b$ ). The recipient site was prepared to receive the graft. The harvested graft was carefully placed over the prepared donor site and sutured under minimal tension using 6-0 Vicryl sutures (Figure 2c). Light pressure was applied over the graft to achieve initial hemostasis and to prevent the formation of an intervening clot, and the surgical wound was covered with a protective periodontal dressing (Figure $2 \mathrm{~d}$ ). The donor site was left to granulate.

Three-week review revealed good healing of both donor and moderate sites, with increased width of keratinized gingiva and moderately good root coverage (Figure 2e). A coronally displaced flap was subsequently performed to improve root coverage further (Figure $2 \mathrm{f}$ ).

\section{Discussion}

Periodontal plastic surgery has been used in several clinical procedures, including those traditionally classified as mucogingival surgery, with little variation in the list. The method used in the cases reported here was the free gingival graft.
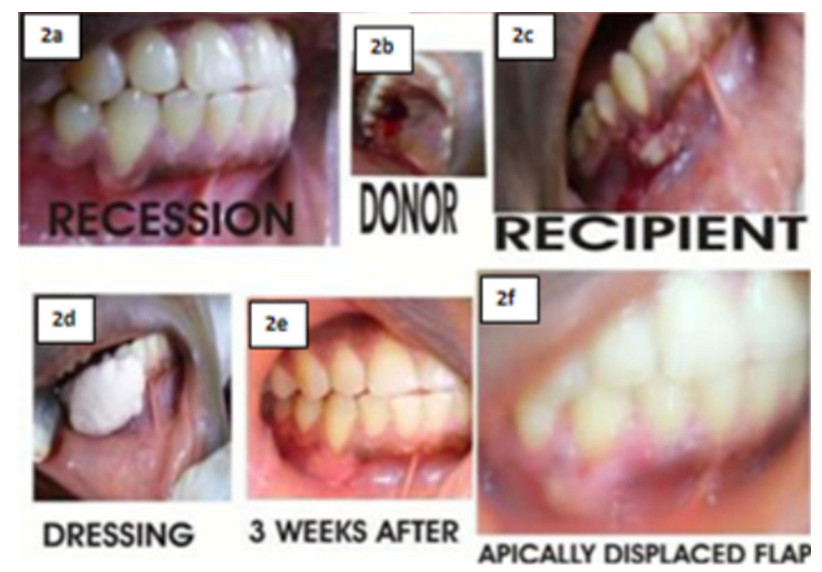

Figure 2 Free gingival autograft for treatment of recession on tooth 43 . 
The first case showed very little coverage, while the second case had a more encouraging result. With the benefit of hindsight, it is probable that the first case could have been better treated with newer techniques, such as the subepithelial connective tissue graft. This method has been found to produce superior results even when compared with guided tissue regeneration.

While the advent of guided tissue regeneration generated a lot of enthusiasm as a root coverage procedure, techniques such as the subepithelial connective tissue graft seem to have shown superior results in achieving greater root defect coverage. It has also proved useful in reconstruction of the interdental papilla. ${ }^{3}$ This view is shared by Chambrone et al ${ }^{4}$ who performed a systematic review of several methods utilized in the coverage of root defects that fit the various Miller's classes of gingival recession.

The presenting complaint and primary objective of periodontal plastic surgery is often cosmetic/aesthetic root coverage. This might be directly connected to real and/or perceived effects of receding gums with aging. ${ }^{5}$ In many instances, however, this is not possible and clinicians have had to settle for a gain in keratinized tissue instead. This result, although often not completely satisfactory to the patient for obvious reasons, at least ensures a halt in the loss of tissues and consequently slowing down of recession.

In a review of 56 cases of various classes of gingival recession, Popova and Boyorova ${ }^{6}$ observed that free gingival autografts increased the width of keratinized gingiva and at times reduced the depth of gingival recession. In contrast, Lee Kan-Ho et al in a recent report observed that the width of keratinized gingiva did not affect the long-term survival of implants. ${ }^{7}$ Certain criteria for success have been reported in the literature. In a recent study ${ }^{8}$ involving 43 single-rooted teeth, Joo et al concluded that the major determinant of success in root coverage using the connective tissue graft is the individual gingival biotype. Unlike previously believed, they found a stronger association between gingival biotype and success than with Miller's classification. They concluded that gingival biotype (the distance from the interproximal papilla to gingiva margin), may be the key determinant of extent of root coverage. It is not clear, however, how this determinant affects gingival autografts, especially in view of other reports that consider severity of recession to be the major determinant of success with gingival autografts. ${ }^{9}$

Other determinants of success reported in literature include the influence of suture size and flap tension. Better results and less tear were obtained with the use of 6.0-7-0 sutures with minimal tension. ${ }^{10}$ The use of 6-0 sutures in the current report is therefore in accordance with reports in literature.

Application of gentle pressure to the flap, as used in the current report, has also been advocated in literature. The suggested duration ranges between two and five minutes. ${ }^{11,12}$ The formation of a thin clot is said to promote tensile strength. ${ }^{13}$ It has therefore been suggested that this pressure application should be used to reduce the dead space and prevent the formation of a "thick" blood clot and increase the chances of success.

Apart from the visible issues affecting the success rate of such complex procedures, clinicians in developing counties like Nigeria are faced with many hidden challenges, prominent among which is cost.

Cost, as observed by Amaghionyeodiwe,${ }^{14}$ is the major determinant of utilization of health services in Nigeria. This observation is corroborated by Katung ${ }^{15}$ who found that cost-related issues were the determinants of health service utilization in $48 \%$ of respondents in a Nigerian rural community.

Closely related to the issue of cost is the frustrating issue of the Nigerian National Health Insurance Scheme. This scheme commenced in 2003 and currently enjoys very high awareness, as reported by Sanusi and Awe in a recent survey. ${ }^{16}$ However, it is plagued with lack of public confidence and an unwillingness to pay for community-based health insurance. ${ }^{17}$ The reaction of many Nigerians to the scheme is that of "once bitten, twice shy".

This view is borne out by the fact that the Nigerian government has not shown enough political will to convince the public of its commitment to the health of its over 150 million population, as revealed by a recent World Health Organization report. ${ }^{18}$ The public spending per capita for health in Nigeria ranges between USD2 and USD5, as against the USD34 for low-income countries advocated in the Macroeconomics Commission Report.

Equally important in the provision and utilization of such specialized services as periodontal plastic surgery in Nigeria is the issue of dental awareness. Savage, in a pilot study of periodontal disease awareness amongst Nigerians, ${ }^{19}$ found that the major reason for dental visits in Nigeria is toothache and/or extraction. The demand for cosmetic periodontal procedures is still very low and virtually unknown to most Nigerians.

In addition, the dearth of expertise, worsened by the "brain drain", adds another dimension to the challenge. 
Suleiman $^{20}$ reported that there are 21,000 Nigerian doctors practicing in the US alone. Closely tied to the dearth of expertise is the suspension of funding for the one-year overseas training scheme which was a very valuable tool for exposure of Nigerian specialists-in-training to current practice and advances in the developed world, an issue which is now the subject of industrial action between resident specialist doctors and dentists in training and the Nigerian government. ${ }^{21}$

Despite the challenges, these procedures are still being performed in Nigeria against all odds. The options have been no treatment at all or use of gingival prostheses, as reported by Savage and Nwhator. ${ }^{22}$

As a last resort, when it becomes imperative to perform these procedures, patients are offered the option of purchasing all the materials needed, in return for very highly subsided surgery fees. This way, the patient benefits and the dentists in training get the opportunity of watching interesting and technique-sensitive periodontal plastic surgery procedures. It was the adoption of this last resort that resulted in the two cases reported.

For most Nigerians, periodontal plastic surgery would appear to be a luxury rather than a necessity. The most important factor militating against the utilization of such services relates more to awareness than to perceived need.

Dental awareness is still very low in Nigeria, although the last few decades seem to have witnessed some improvement. It is very unlikely that any program will be put in place in the near future, because the concern now is to get the teeming population to understand the basic need to visit the dentist at least twice a year rather than focusing on specialized dental treatments.

Onoriobe et $\mathrm{a}^{23}$ in a recent conference abstract presented at the conference of International Association for Dental Research, captures the situation in Nigeria where they reported that dental clinics were not considered when hospitals were being planned. It takes almost an hour's journey to access the nearest government dental clinics in some areas.

Although periodontal plastic surgeries are now being attempted in specialist dental clinics, unfortunately, for most of Nigeria's over 150 million population, it is a luxury to access a clinic where they could get even a simple dental filling.

\section{Conclusion}

The two cases reported here achieved different levels of success. While complete root coverage could not be achieved, both cases showed a gain in width of keratinized gingiva, while one case showed good root coverage. The case with better root coverage was augmented with a coronally displaced flap. There are challenges facing the continued provision of such highly specialized services, but Nigerian doctors and dentists are rising to the challenge and providing these services against all odds.

\section{Disclosure}

The author reports no conflict of interest in this work.

\section{References}

1. Friedman N. Mucogingival surgery. Tex Dent J. 1957;75:358-362.

2. Burkhardt R, Hürzeler MB. Utilization of the surgical microscope for advanced plastic periodontal surgery. Pract Periodontics Aesthet Dent. 2000;12(2):171-180.

3. Desai S, Shinde H, Mudda J, Patil V. Simultaneous surgical excision of localized gingival overgrowth and papilla reconstruction with subepithelial connective tissue graft: A case report. The Internet Journal of Dental Science. 2009;8(1). Available from: http://www.ispub.com/journal/the_ internet_journal_of_dental_science/volume_8_number_1_19/article/ simultaneous-surgical-excision-of-localized-gingival-overgrowth-andpapilla-reconstruction-with-subepithelial-connective-tissue-graft-acase-report.html. Accessed on Jul 6, 2010.

4. Chambrone L, Sukekava F, Araújo MG, Pustiglioni FE, Chambrone LA, Lima LA. Root-coverage procedures for the treatment of localized recession-type defects: A Cochrane systematic review. J Periodontol. 2010;81(4):452-478.

5. Five things you must do to age beautifully. CNN.com/living. 2007 Aug 13. Available from: http://edition.cnn.com/2007/LIVING/ personal/08/13/o.age.beautifully/index.html. Accessed on Jul 6, 2010.

6. Popova C, Boyarova T. Free gingival autograft for augmentation of keratinized tissue and stabilization of gingival recessions. Journal of IMAB Annual Proceedings (Scientific Papers). Book 2, 2008. Available from: http://www.journal-imab-bg.org/statii-08/vol08_2_19-25str.pdf. Accessed on Jul 6, 2010.

7. Kang-Ho Lee, Byung-Ock Kim, Hyun-Seon Jang . Clinical evaluation of a collagen matrix to enhance the width of keratinized gingiva around dental implants. J Periodontal Implant Sci. 2010;40:96-101.

8. Joo JY, Lee JY, Kim SJ, Choi JI. Influence of gingival biotype on the amount of root coverage following the connective tissue graft. J Korean Acad Periodontol. 2009;39(2):111-118.

9. Deepalakshmi D, Arunmozhi U. Root coverage with free gingival autografts - a clinical study. Ind J Dental Res. 2006;17(3):126-130.

10. Preiss A, Joss A, Lang NP. Influence of suture tension to the tearing characteristics of the soft tissues: An in vitro experiment. Clin Oral Implants Res. 2008;19(3):314-319.

11. Huang LH, Neiva RE, Wang HL. Factors affecting the outcomes of coronally advanced flap root coverage procedure. J Periodontol. 2005;76(10):1729-1734.

12. Wong D. Periodontal plastic surgery. Predictable root coverage in the mandibular incisor region. Case presentation. Periodontics Town. Jan 2005. Available from: http://thetulsainstitute.com/Dentaltown $\% 20$ article\%20reprint.pdf. Accessed on Jul 6, 2010.

13. Bouchard P, Malet J, Borghetti A. Decision-making in aesthetics: Root coverage revisited. Periodontol 2000. 2001;27:97-120.

14. Amaghionyeodiwe LA. Determinants of the choice of health care provider in Nigeria. Health Care Manag Sci. 2008;11(3):215-227.

15. Katung PY. Socio-economic factors responsible for poor utilisation of the primary health care services in a rural community in Nigeria. Niger J Med. 2001;10(1):28-29.

16. Sanusi RA, Awe AT. An assessment of awareness level of National Health Insurance Scheme (NHIS) among health care consumers in Oyo State, Nigeria. Pak J Soc Sci. 2009;6(1):48-63. 
17. Onwujekwe O, Okereke E, Onoka C, Uzochukwu B, Kirigia J, Petu A. Willingness to pay for community-based health insurance in Nigeria: Do economic status and place of residence matter? Health Policy Plan. 2010;25(2):155-161.

18. World Health Organization. WHO African Region: Nigeria. Health financing and social protection. Available from: http://www.who. int/countries/nga/areas/health_financing/en/index.html. Accessed on Jul 6, 2010.

19. Savage KO. A pilot study of periodontal disease awareness amongst Nigerians. Afr Dent J. 1994;8:30-35.

20. Suleyman AM. Effect of Skilled Migration on Economic DevelopmentA Global Perspective. Presented at: First African Convention. Kuching Sarawak Malaysia. 2005 Jan 8. Available from: http:// en.wikisource.org/wiki/Effect_of_Skilled_Migration_on_Economic_ Development_\%E2\%80\%93_A_global_Perspective. Accessed on Jul 6, 2010.
21. Strike: Resident Doctors Issue 21-Day Ultimatum. This Day Newspaper Nigeria. Available from: http://www.thisdayonline.com/nview. php?id=174171. Accessed on Jul 6, 2010.

22. Savage KO, Nwhator SO, Ayanbadejo PO. Gingival prosthesis: An alternative to surgery in multiple-site gingival recession. Nig Q J Hosp Med. 2005;15(4):184-185.

23. Onoriobe UE, Adekugbe Y, Osakpamwan I . Smile Africa Dental Society, Jos, Nigeria. Accessibility of rural dwellers in Nigeria to dental centres. The Preliminary Program for 5th Annual Scientific Congress of IADR Nigerian Division; August 29-September 1, 2006. Available from: http://iadr.confex.com/iadr/niger06/preliminaryprogram/ abstract_87734.htm. Accessed on Jul 6, 2010.

\section{Publish your work in this journal}

Research and Reports in Tropical Medicine is an international, peerreviewed, open access journal publishing original research, case reports, editorials, reviews and commentaries on all areas of tropical medicine, including: Diseases and medicine in tropical regions; Entomology; Epidemiology; Health economics issues; Infectious disease; Laboratory science and new technology in tropical medicine; Parasitology; Public health medicine/health care policy in tropical regions; and Microbiology. The manuscript management system is completely online and includes a very quick and fair peer-review system. Visit http://www.dovepress. com/testimonials.php to read real quotes from published authors.

Submit your manuscript here: http://www.dovepress.com/research-and-reports-in-tropical-medicine-journal 